Proc. Indian Acad. Sci. (Earth Planet. Sci.), Vol. 89, Number 2, July 1980, pp. 179-195.

(C) Printed in India.

\title{
Some aspects of the large scale fluctuations of summer monsoon rainfall over India in relation to fluctuations in the planetary and regional scale circulation parameters
}

\author{
D R SIKKA \\ Indian Institute of Tropical Meteorology, Pune 411 005, India \\ MS received 19 August 1979 ; revised 19 April 1980
}

\begin{abstract}
Year-to-year fluctuations of summer monsoon (June-September) rainfall of India are studied in relation to planetary and regional scale features. Anomalous epochs in the monsoon rainfall have been found to coincide with the epochs having anomalous patterns of temperature distribution in the northern hemispheric extratropics as well as with the spells of years having anomalous patterns of sea surface temperature distribution in the equatorial Pacific Ocean (EL-Nino phenomenon).

Relationship between monsoonal rainfall and regional atmospheric circulation features is studied by compositing data of five good and five bad monsoon rainfall years over India. A comparison of the two data sets yields interesting relationships between the anomalous patterns of rainfall on the one hand and atmospheric parameters on the other. On the average parameters of monsoon depressions are more or less the same among the two types of composites. The most important distinguishing feature of good monsoon years is the greater frequency of cyclogenesis (monsoon lows included) on the regional scale which keeps the monsoon trough near its normal position and with concomitant higher cyclonic vorticity in the trough zone contributes to greater seasonal rainfall on the regional scale during good monsoon years.
\end{abstract}

Keywords. Summer monsoon fluctuations; monsoon rainfall; regional atmospheric circulation; southern oscillation.

\section{Introduction}

Climatologically the summer monsoon circulation (June to September) over the Indian sub-continent is of great significance because the bulk of the annual rainfall over most of India is accounted by this season. As such the socio-economic consequences of widespread drought conditions during the season are very grave. The first major work on the subject 'Rainfall of India' was written by Blanford (1882) nearly a century ago. Recent studies by Ramage (1971), Rao (1976), etc. discuss different aspects of the monsoon circulation and rainfall on different temporal and spatial scales, etc. Detailed studies of some specific drought years have been also carried out by Dallas (1900), Ramage (1969), Keshavamurti and Awade (1974), Sikka and Gadgil (1978), Kanamitsu and Krishnamurti (1978) 
and several others. More diagnostic studies on major fluctuations of monsoon seasonal rainfall in relation to fluctuations in the large scale atmospheric circulation features are likely to yield much needed information on the short term climatic fluctuations leading ultimately to improvement in long range weather prediction. The present paper is an attempt in this direction.

In $\S 2$ we discuss the major fluctuations observed in the historical records of the monsoon rainfall series and link the anomalous epochs of rainfall with the two major circulation features i.e. (i) the meridional circulation (Hardley circulation) as determined by the variations in the northern hemisphere tropospheric temperature field and (ii) the southern oscillation or the Walker circulation in the Indo-Pacific equatorial region as determined by the well-known El-Nino Phenomenon. Section 3 concerns itself with the discussion of some of the large scale circulation features as observed over India and neighbourhood in contrasting (good and bad monsoon rainfall) seasons based on the composite data of recent years in either category. Concluding remarks are offered in $\S 4$.

\section{Planetary scale aspects}

The meridional circulation ( $y-p$ plane) and the east-west circulation $(x-p)$ play prominent roles in driving the large scale circulations over the tropics. Monsoons are thermally forced phenomena and as such any year-to-year variations in the asymmetric heating pattern over the regional/planetary scale is likely to influence the performance of the Indian monsoon.

The region of the seasonal summer monsoon trough over the Gangetic plains of India is the seat of a major updraft. Thus on the regional scale, the southerly flow which prevails over India during summer in the lower troposphere, rises upward over the region of monsoon trough and then returns as the northerly flow over peninsular India and across the equator. This direct vertical circulation is usually considered as the regional monsoon Hadley Cell (Koteswaram 1960) whose southward-directed branch in the upper troposphere produces the Tropical Easterly Jet. The performance of this circulation may be influenced by the large scale changes in the distribution of tropospheric temperature over the northern hemisphere Eurasian region in the meridional direction.

Walker $(1924,1928)$ brought into prominence a large scale oscillation in the sea level pressure over the tropics. This oscillation is known as the Southern Oscillation (S.O.) which determines the out-of-phase pressure relationship in the south Pacific/south American region with the Indonesian/Indian Ocean region. The work of Bjerkenes (1969) on the S.O. suggests that the S.O. has a role in the redistribution of heat sources and sinks in the equatorial region which in turn influence the related general circulation over the Indo-Pacific region. Bjerkenes termed this prominent east-west circulation as the thermally driven Walker Circulation which has a rising branch near $100^{\circ} \mathrm{E}$ (over the warmer waters of west Pacific and Indonesia) and a sinking branch near $100^{\circ}-120^{\circ} \mathrm{W}$ (over the colder waters of equatorial mid-Pacific). Krishnamurti (1971), from the study of upper tropospheric winds, pointed out that the Walker Circulation is part of the global east-west over-turning and its strength is almost equivalent to the regional Hadley 
circulation over India during the summer season. Bjerkenes also suggests that the variation of S.O. Walker circulation is mainly a zonal wave number one phenomenon. When the S.O. is intense the southeast Pacific high would be welldeveloped and the SE trades over the south Pacific are expected to be stronger which in turn would result in pronounced upwelling along the south American coast (Peruvian coast). The spreading of these cold waters of the Peru current towards the equatorial mid-pacific as well as the equatorial upwelling, resulting from stronger trades, would produce considerable cooling of SST with consequent supression of convection and unusally dry weather over the equatorial eastern, central and western Pacific. There are years when the S.O. is considerably weak which results in warmer waters along the Peruvian coast and equatorial Pacific with consequent increase in convective activity and rainfall over the dry equatorial Pacific zone. The years of abnormally high SST from the west coast of S. America towards the equatorial mid-pacific are known as EL-Nino years and the years of abnormally colder waters in the same region are known as counter El-Nino years.

We now examine epochs of major fluctuations of Indian monsoon rainfall with respect to major fluctuations in the northern hemispheric tropospheric temperature and the major El-Nino events in the S.O. system.

\subsection{Northern hemisphere tropospheric temperature and monsoon rainfall}

Parthasarathy and Mooley (1978) prepared a homogeneous series of seasonal monsoon rainfall over India extending over a period of over 100 years. Their data for the standard decades show continuous increases of rainfall for the epoch 1921-1950 followed by a decrease for the epoch 1951-1970. The authors find that the three standard decades covered by the increasing rainfall (1921-1950) were also characterised by rather low coefficient of variation. Figure 1 shows the plots of decadal anomalies of the Indian monsoon rainfall, its standard

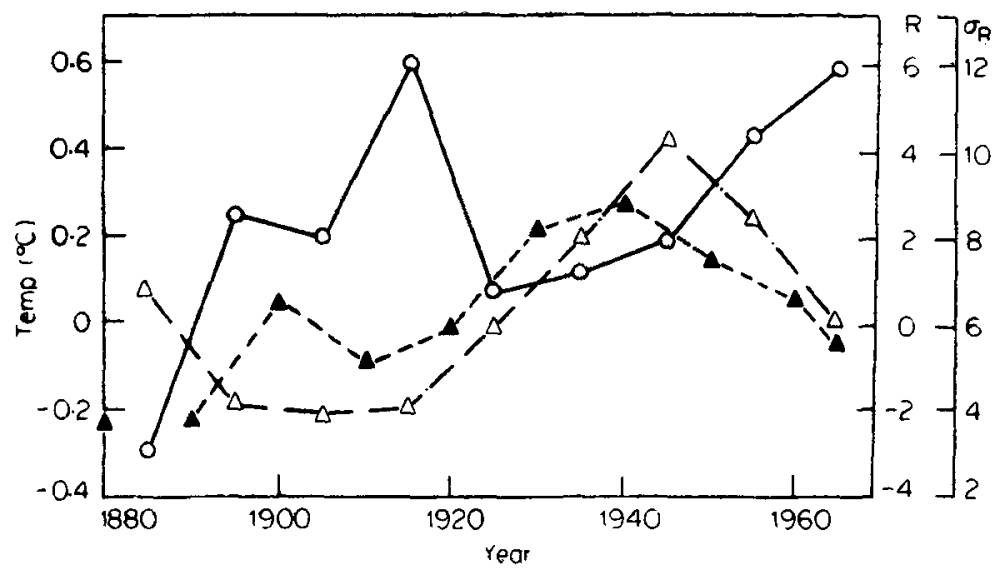

Figure 1. Decadal anomalies of monsoon season rainfall, its standard deviation and the decadal anomalies of northern hemisphere surface temperature. 
deviation and the decadal anomalies of the northern hemisphere surface temperature. The temperature data is based on the deviation from the average of 1875-1975 reported by Miles (1978). It is seen that the epoch 1921-1950 (three decades), which shows increase of monsoon rainfall and general decrease in its variability, has been associated with general increase in the northern hemispheric surface temperature. Similarly, the epoch 1951-1970 (two decades), which shows decrease in rainfall and increase in its standard deviation, is accompanied by lower than normal surface temperature in the northern hemisphere.

Harley (1978) examined the deviation of $1000-500$ mb thickness over the northern hemisphere for the period 1949-1976 and found that the period 1950-1964 is accompanied by more or less above normal values and below normal values are observed in the data from 1965 onwards. The data presented by Angell and Korshover (1977) also suggests a lower temperature in the troposphere of the northern hemisphere during the years 1965-75. The tropospheric cooling is marked in the mid-latitudes and there is some evid nce for slight warming in the tropics. This would mean that the westerly circulation of the mid-latitudes during the decade 1965-75 has expanded towards the tropics due to increase of meridional temperature gradient with the consequent adverse effect on the building up of the monsoons on the decadal scale. Although it is not possible to explain fluctuations of the northern hemisphere tropospheric temperature, it is important to bear in mind that epochs of abnormal monsoon rainfall are however related to the epochs of abnormal tropospheric temperature in the northern hemisphere. Matson (1977) reported data of the satellite derived snow cover over northern hemisphere for the period 1966-77. It shows that the Eurasian winter snow cover began to rise from 1969-70 and touched the highest value in February-March 1972-preceding the devastating failure of monsoon in the 1972 season. However good performance of monsoon in 1975 and 1976 when the Eurasian snow cover was high and the bad performance in 1974 when the snow cover showed decrease again point to the futility of simple explanations to the fluctuations of monsoon rainfall.

\subsection{SO-El-Nino phenomenon and their possible linkage with large scale per- formance of monsoon rains over India}

Quinn (1974) showed that the SO index is appropriate for monitoring the ElNino events. Reiter (1978) linked the El-Nino episodes with the abrupt increase in the Line Island precipitation index. His study showed that there have been three distinct epochs in the Line Island precipitation index since 1910. The two epochs which occurred during the years 1911-1928 and 1963-75 are accompanied with frequent surges of precipitation sometimes occurring with a periodicity of quasi-biennial nature. The third epoch which lasted between 1929-1962 is characterised by irregular and infrequent surges of precipitation. It is rather interesting to find that there is some similarity in these three epochs with the epochs of major fluctuations in the Indian monsoon rainfall. The major epochs of the fluctuations of the Indian monsoon rainfall have been also reported by Joseph (1976). In the two epochs 1911-20, and 1963-75 (total period 23 years) there have been 
Table 1. El-Nino events and monsoon rain failures (period 1875-1975).

\begin{tabular}{cccc}
\hline $\begin{array}{c}\text { Years of monsoon failure } \\
\text { which were El-Nino years } \\
\text { too }\end{array}$ & $\begin{array}{c}\text { Years of } \\
\text { monsoon } \\
\text { failure but } \\
\text { not El-Nino } \\
\text { years. }\end{array}$ & $\begin{array}{c}\text { Years of El-Nino } \\
\text { but not monsoon } \\
\text { failure. }\end{array}$ \\
$\begin{array}{c}\text { El-Nino } \\
\text { Years }\end{array}$ & $\begin{array}{c}\text { Monsoon } \\
\text { failure years }\end{array}$ & & \\
\hline 1877 & 1877 & 1901 & $1921-22$ \\
1899 & 1899 & 1920 & $1923-24$ \\
1905 & 1905 & 1966 & $1925-26$ \\
$1911-12$ & 1911 & & $1930-31$ \\
$1913-14$ & $1913 *$ & & $1956-58$ \\
$1914-15$ & $1915 *$ & & $1963-64$ \\
$1918-19$ & 1918 & & $1969-70$ \\
$1927-28$ & 1928 & & \\
$1939-40$ & $1939 *$ & & \\
$1940-41$ & 1941 & & \\
$1951-53$ & 1951 & & \\
$1965-66$ & 1965 & & \\
$1968-69$ & 1968 & & \\
$1972-73$ & 1972 & & \\
$1974-75$ & 1974 & & \\
\hline 15 years & & & \\
\hline & & & \\
\hline
\end{tabular}

* Years of minor failure of monsoon rainfall.

8 years $(1911,1918,1920,1965,1966,1968,1972,1974)$ of major failure of monsoon rainfall ( $\leqslant 10 \%$ of the normal). The epoch 1929-62 (34 years) is marked by rarity of droughts over India as the rainfall failed only in two years (1941 and 1951) in this epoch.

Table 1 shows the relationship of the El-Nino years with the performance of the monsoon rainfall. For this purpose we have used the data given by Reiter (1978) for the years 1910 to 1974 for specification of El-Nino years from the Line Island precipitation Index. The data given by Mossmann (1924) on the SO for the years 1875-1914 has been also used to extend the history of El-Nino occurrence backward. The years of monsoon rainfall failures are based on the work of Parthasarathy and Mooley (1978). The preliminary relationship presented above, with respect to the number of El-Nino years associated with a large number of monsoon failures over India, points out to the desirability of further work in this direction. The very indication that in some years or epochs an out-of-phase relationship exists between the poor performance of the monsoon rains over India and the abnormal rain over the eastern/central Pacific, suggests very large scale teleconnections which operate through the displacement of the east-west circulation resulting from the changes in the thermal forcing in the equatorial regions on the planetary scale. 


\subsection{Sequence in the occurrence of El-Nino vis-a-vis monsoon failure}

It is tempting to investigate whether the El-Nino event of eastern/central Pacific precedes the failure of monsoon season rainfall or vice versa as this may have value in the long range prediction of either event. Data for such a study are lacking at present. The data presented by Reiter (1978) on the Line Island precipitation index show that the highest value of the index in different high index years is reached in all parts, i.e., the beginning, middle or end of a year. However, the remarkable El-Nino event of 1972 investigated in detail by Ramage (1977) showed that the warming of the waters of the eastern Pacific began in May-June, 1972 , i.e., just at the time of the commencement of monsoon season in India but it achieved the highest value $\left(5^{\circ} \mathrm{C}\right.$ warmer than normal) during September to December 1972, i.e., just after the major deficiency in the monsoon rainfall had occurred. Chiu and Lo (1979) have recently statistically investigated the relationship between the fluctuations of $250 \mathrm{mb}$ zonal winds over the Indian monsoon region and fluctuations of SST over the El-Nino area and found the former leading the latter by two months. They also found that weaker than normal easterlies at $250 \mathrm{mb}$ over the Indian region (indicative of weaker monsoon circulation) are related to warmer than normal SST in the mid-Pacific (indicative of E1-Nino event) two months later.

Murakami (1974) performed a numerical experiment with a nonlinear ninelayer spectral model with the anomalous heat source specified as an external parameter either over the Indian monsoon region or over the equatorial Pacific. Interestingly, he found that the teleconnections between the two regions occurred in one direction only, i.e., heating anomaly prescribed over the monsoon region excited a strong response in the zonal winds over the equatorial central Pacific while an equatorial heating anomaly did not cause any significant change in the monsoon circulation. Rowntree (1978) performed a numerical experiment with the U.K. Meteorological office general circulation model (GCM) to study the effect of tropical Pacific SST anomaly as observed during the summer of 1972 on the circulation features. He found that warmer SST over the equatorial Pacific gave increased precipitation over the central equatorial Pacific and compensatory decrease in precipitation over western Pacific and S. Asia.

Neither the fragmentary observational evidence nor the results of the numerical experiments mentioned above conclusively answer the question as to the exact relationship in time domain between the occurrence of warm SST/increased precipitation over the equatorial Pacific and its response to the performance of monsoon rainfall or vice versa. What perhaps can be said at this stage is that although the atmosphere and oceans are intimately coupled in the climatic scale, the teleconnections resulting from their interactions are very complex as the climatic system cannot be strictly studied in isolation. It is tempting to recall here the remarks of Normand (1953) about the long range forecasting of monsoon "Indian rainfall has its connections with later rather than earlier events. The Indian monsoon, therefore, stands out as an active and not a passive feature in world weather, more efficient as a broadcasting tool than an event to be forecast". 


\section{Regional aspects - Variations in monsoon circulation parameters over India in} years of good and bad monsoon rainfall

Year-to-year fluctuations in the weather elements over the tropics are best depicted by the variations in the seasonal rainfall. Hasternath (1976) and Lamb (1978) examined the large scale circulation anomalies in some of the surface weather parameters and SST associated with extreme rainfall years over tropical Americas and the sub-Saharan region. Their approach of comparing composites for the collection of extreme rainfall years in terms of patterns of circulation anomalies have yielded extremely useful information in understanding the dynamics of tropical climate. They found significant changes between the wet and the dry years in several circulation parameters such as the position and intensity of the Inter tropical convergence zone (ITCZ), position and intensity of the sub-tropical highs, strength of the trade winds, changes in the patterns of SST, etc. The sign of departure patterns from the normal being reverse in wet years in comparison to those in the dry years. In view of these results, it is worthwhile to examine the regional features of monsoon circulation over India in the composites of good and bad monsoon rainfall years.

\subsection{Composite features of the good and bad monsoon years}

We have chosen to compare the composited data for the recent bad monsoon years over India consisting of 1965, 1966, 1968, 1972 and 1974 and good monsoon years consisting of $1961,1967,1973,1975$ and 1976. For the bad monsoon years chosen above, area averaged negative anomaly of the seasonal monsoon rainfall for the mainland of India varied between 11 to $23 \%$ (1972 being the year in which the anomaly was $-23 \%$ ). The positive anomaly for the good monsoon seasons varied between $2 \%(1967)$ to $29 \%$ (1975). The mean anomaly for the sets of five bad and five good monsoon years was $-16 \%$ and $+16 \%$ respectively. The composites were prepared for the month of July and August as well as for the period July-August. The features examined in the composites are the following:

(i) Anomaly of the position of monsoon trough,

(ii) Anomaly of sea level pressure (SLP) field,

(iii) SLP difference between the stations Colombo $\left(06^{\circ} 54^{\prime} \mathrm{N}, 79^{\circ} 53^{\prime} \mathrm{E}\right)$ and Nagpur $\left(21^{\circ} 06^{\prime} \mathrm{N}, 79^{\circ} 03^{\prime} \mathrm{E}\right)$ indicate the strength of the monsoon westerlies,

(iv) Difference of $850 \mathrm{mb}$ zonal wind between $20^{\circ} \mathrm{N}$ and $28^{\circ} \mathrm{N}$ along $80^{\circ} \mathrm{E}$ as index of the large scale cyclonic relative vorticity in the monsoon trough zone,

(v) Anomaly of the position of monsoon trough at $700 \mathrm{mb}$,

(vi) Number of monsoon depressions and their tracks,

(vii) Average number of depression days-depression day being characterised by the presence of atleast one depression,

(viii) Average departure of sea level pressure in the central region of the depression,

(ix) Number of 'break' monsoon days,

(x) Number of break monsoon spells.

Table 2 summarises the chief features which emerge as a result of the composited charts for the good and bad monsoon years. 


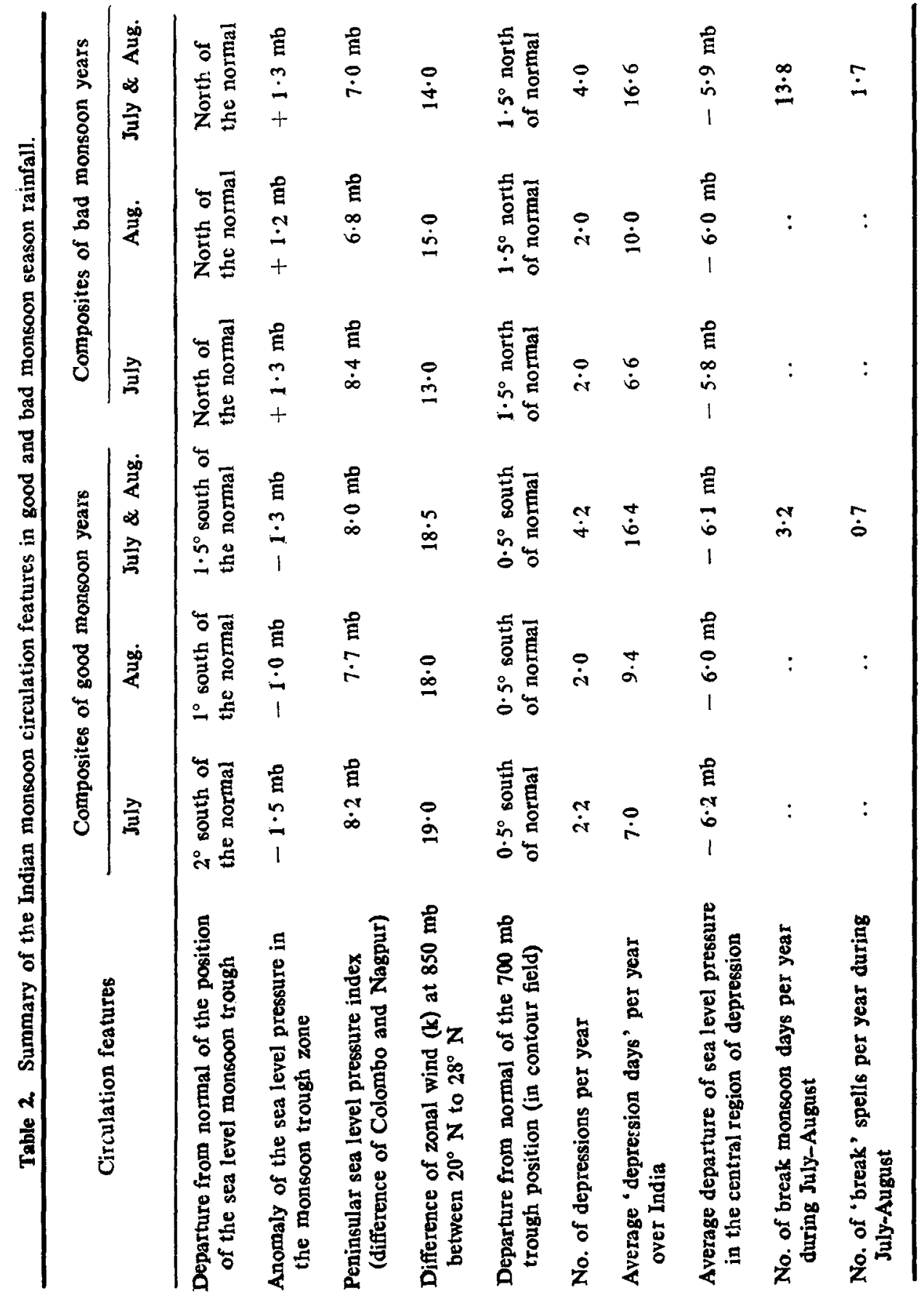


Figure 2 depicts the configurations of the SLP anomaly pattern. We notice that in the years of bad monsoon the SLP anomaly over the central parts of the country is slightly (about $0.5 \mathrm{mb}$ ) positive, while in good monsoon years it is negative (about $1.0 \mathrm{mb}$ ). Figure 3 shows the streamlines for the anomalous wind field at $700 \mathrm{mb}$ during the months of July and August for the bad and good monsoon composites as well as for a typically bad monsoon month (July 1972) and a good monsoon month (August 1961). The differences are most marked in the region of the monsoon trough $\left(20-25^{\circ} \mathrm{N}\right)$, viz., the anomalous winds are markedly cyclonic in the case of good monsoon composite.

There are some subtle differences in the circulation parameters over India between good and bad monsoon years. The position of the surface and $700 \mathrm{mb}$ monsoon trough is somewhat north of the normal in the bad monsoon years composite and it is somewhat south of the normal in good rainfall years. The intensity of the cyclonic shear in the trough zone at $850 \mathrm{mb}$ is more cyclonic in the good rainfall years in comparison to bad rainfall years. The meridional pressure gradient over Peninsular India is also greater in good monsoon years than in the bad years. In general more ' break' monsoon spells with longer duration occur during bad monsoon years than the good monsoon years. In fact, each one of the bad monsoon years in the list was accompanied with prolonged breaks which in a single or in multiple spells added up to more than 14 days; the longest single spell during 19 July-4 August 1972 being the most devastating one. These features are consistent with our definition of good and bad monsoon years which is based on the rainfall criterion. Good rainfall is associated with lower pressure, stronger pressure gradient, greater cyclonic vorticity near the top of the boundary layer in the region of monsoon trough and less number of 'break' days and the reverse is the case for the bad monsoon years.

\subsection{Influence of monsoon depressions/lows on the performance of monsoon rains}

The unusual aspects which are seen in table 2 are that good and bad monsoon years are a priori not distinguishable from the number of monsoon depressions,

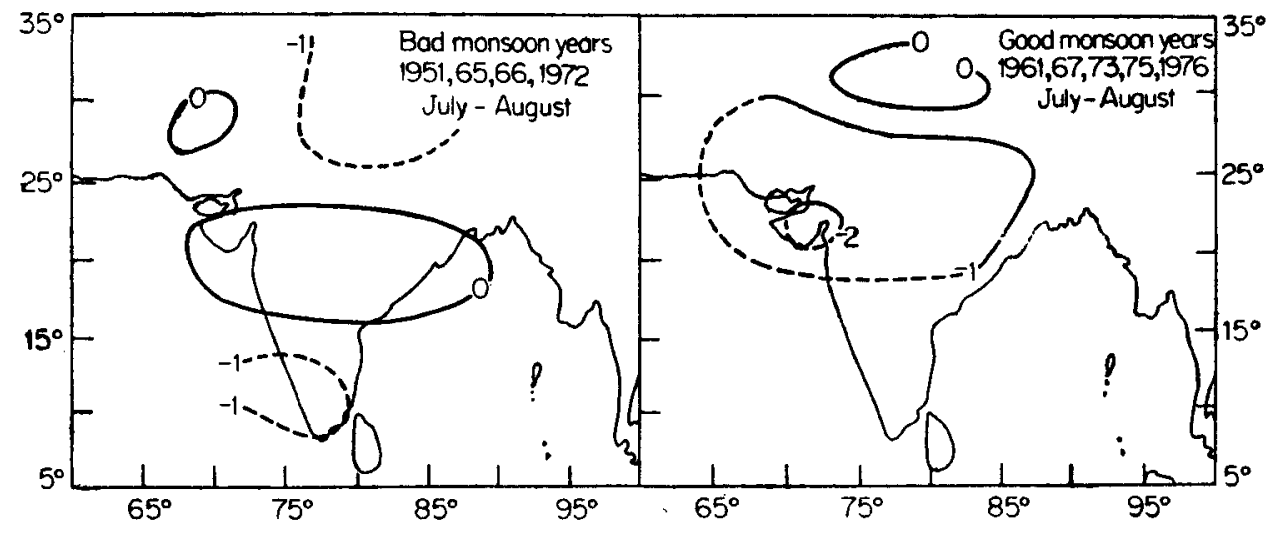

Figure 2. Sea-level pressure anomaly (mb) patterns for the composites of bad and good monsoon rainfall years over India. 

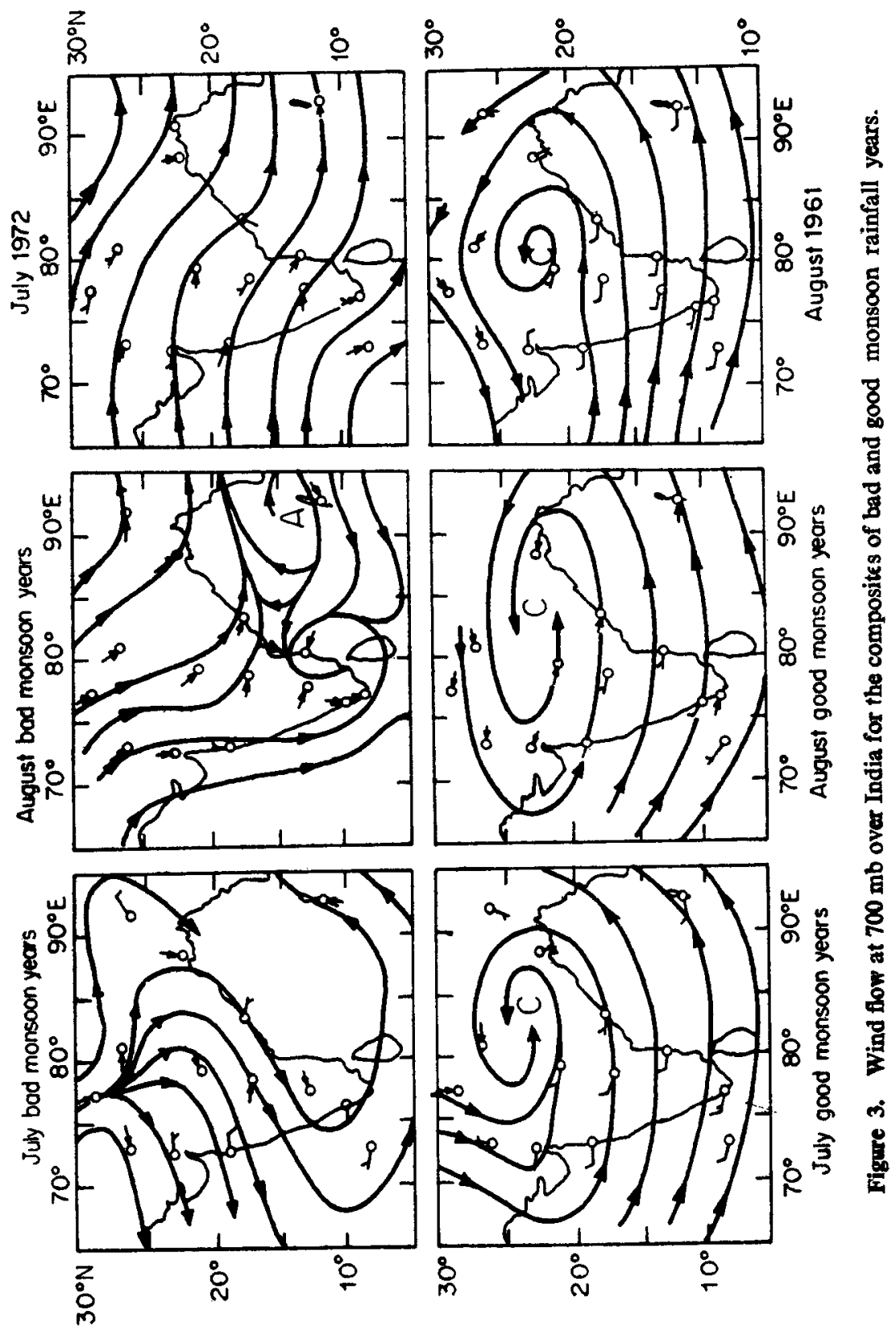
the number of depression days over India and the pressure anomaly at the centre of depression. Similarly, the tracks of the depressions in the two categories of years as shown in figure $4(\mathrm{a}, \mathrm{b})$ are collectively similar. Dhar et al (1978) also showed that the number of monsoon depressions in a year does not show the performance of the monsoon seasonal rainfall over India. This is rather perplexing as monsoon depression is one of the most important synoptic scale disturbances which distributes rainfall over major parts of India in space and time. The horizontal scale of monsoon depression is about $2000 \mathrm{~km}$ and it is found to be not significantly different between good and bad monsoon years. However, it is important that a monsoon depression is an intense synoptic scale disturbance which organises the distribution of rainfall over its own scale (Sikka 1977) in such a way
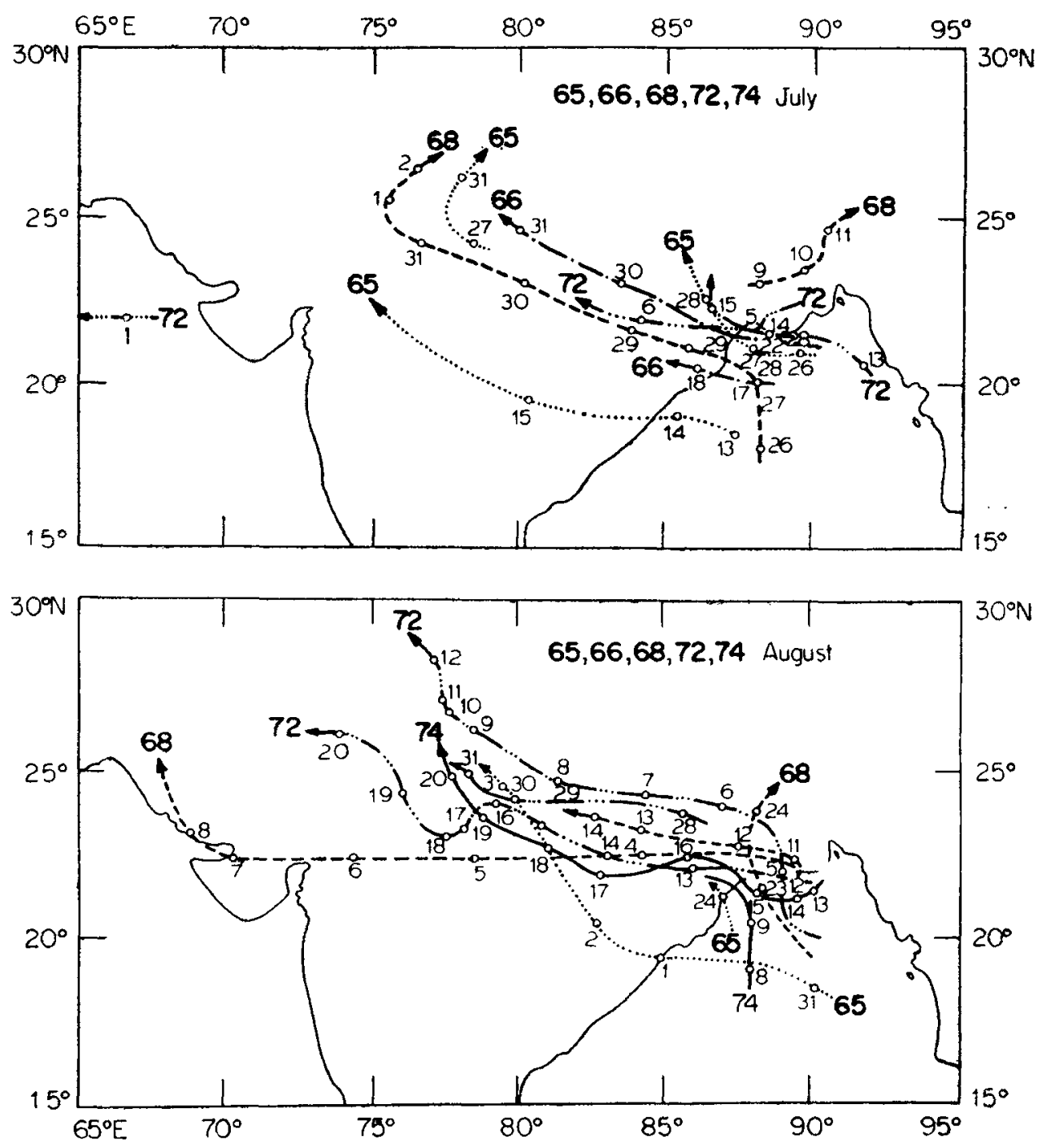

Figure 4a. Tracks of monsoon depressions for the months of July and August during bad monsoon rainfall years. 

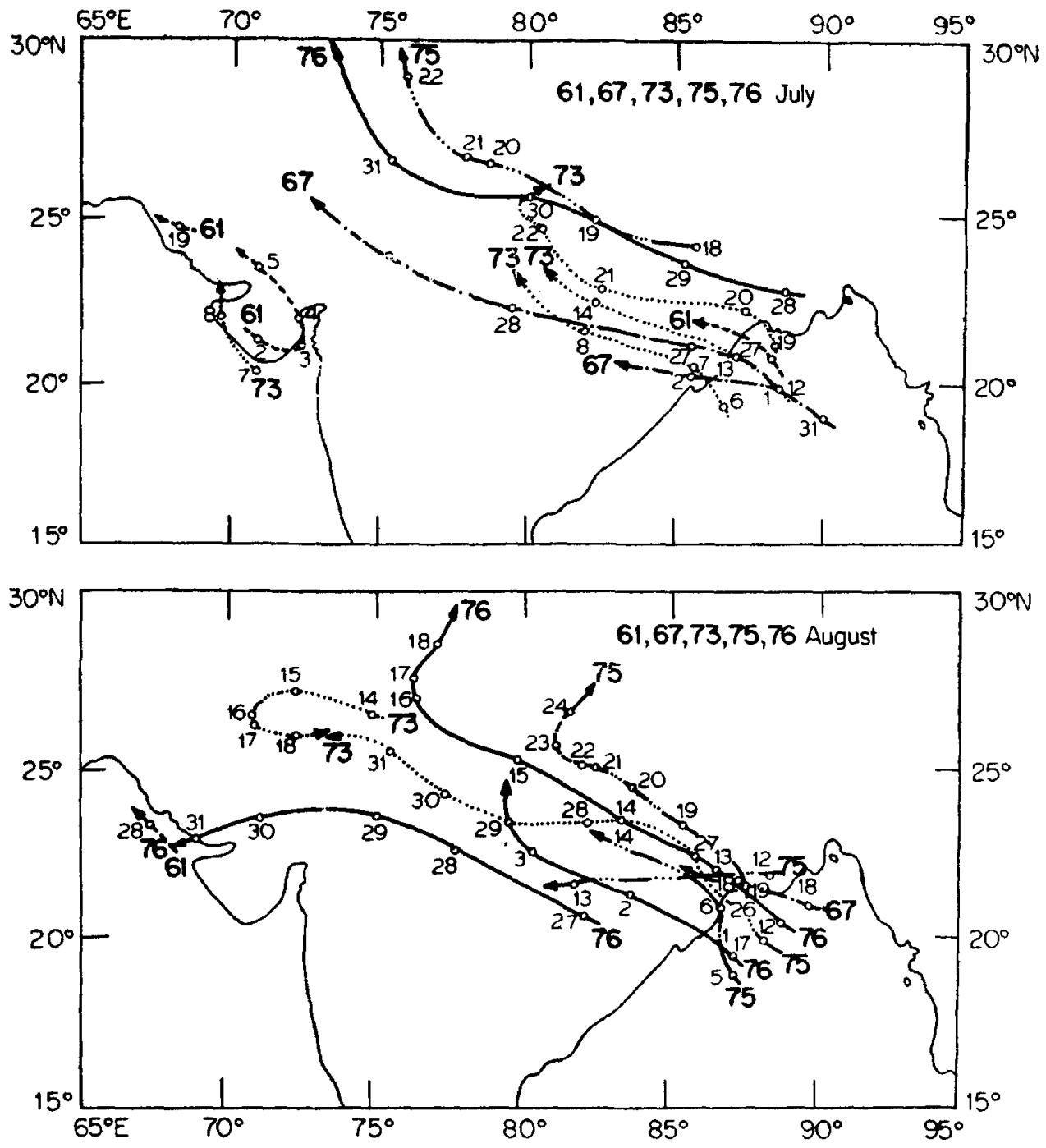

Figure 4b. Tracks of monsoon depressions for the months of July and August for the good monsoon rainfall years.

that large areas to the north of the centre as well as at distances farther away than five degree latitude south of the centre of the depression, suffer from decrease of rainfall. Hence a monsoon depression perhaps does not make any marked difference to the rainfall over the country as a whole as heavy rainfall in the vicinity of a depression is compensated by decreased rainfall in other parts. Substantial amount of rainfall in the monsoon season is due to large scale spatial and temporal oscillations in the position and intensity of the monsoon trough itself. In addition, weaker low pressure systems (lows) which form more frequently than the depressions within the monsoon trough could contribute significantly to the total seasonal rainfall. Some of the lows move over a great part of the monsoon 
trough zone and have life durations of 3 to 6 days. Hence such lows differ only marginally from monsoon depressions. Paul and Sikka (1975) discussed various features of monsoon lows. It is not easy to isolate the effects of different synoptic systems in the lower, middle and upper troposphere which modulate the rainfall distribution over different parts of India during monsoon season. In the following we make an attempt to determine the role of monsoon lows vis- $a$-vis depressions.

The sea level weather charts for the 03 GMT for July and August for the good and bad monsoon years under consideration were individually examined. The area considered was between $70-90^{\circ} \mathrm{E}$ and $15-28^{\circ} \mathrm{N}$ which is the region of the monsoon trough and its normal fluctuations in the latitudinal direction. Only those lows were considered which lay within the above domain and had at least one closed isobar ( $2 \mathrm{mb}$ interval) with a minimum radius of 2 degrees longitude (about $400 \mathrm{~km}$ in horizontal extent). The life history of these lows were followed at subsequent $24 \mathrm{hr}$ intervals and if it could not be located on the subsequent 03 GMT chart its life duration was reckoned as only one day. A low which could be traced for the subsequent day of its formation was reckoned as two days duration and so on. There were days when two lows/two depressions could be located within the same domain or one low and one depression existed simultaneously. Such a day was reckoned as 'depression day' if at least one depression existed or a 'low day' if only lows existed simultaneously.

The days when one or more depression(s)/low(s) existed are categorised as 'disturbed days' and the days when neither a depression nor a low existed are defined as undisturbed days.

Table 3 gives the statistics about the life duration days for depressions and lows separately for good and bad monsoon years. The average life duration of a depression or a low in the composited good and bad monsoon years is again not significantly different. Table 4 summarises the statistics about a number of other parameters. The two categories of composites are clearly distinguishable in terms of parameters other than those associated with depressions given in table 3 .

Table 3. Life duration of monsoon depressions and monsoon lows over India in composited good and bad monsoon years (July and August).

\begin{tabular}{|c|c|c|c|c|c|c|c|c|c|c|c|c|}
\hline \multirow{2}{*}{$\begin{array}{l}\text { Composited } \\
\text { years type }\end{array}$} & \multirow{2}{*}{$\begin{array}{l}\text { Monsoon } \\
\text { system }\end{array}$} & \multicolumn{10}{|c|}{ Life duration/days } & \multirow{2}{*}{$\begin{array}{l}\text { Average life } \\
\text { duration (days) }\end{array}$} \\
\hline & & 1 & 2 & 3 & 4 & 5 & 6 & 7 & 8 & 910 & & \\
\hline Good monsoon & Depression & 3 & 2 & 5 & 3 & 3 & 3 & 1 & 1 & 0 & $\mathbf{0}$ & $4 \cdot 0$ \\
\hline Bad monsoon & Depression & 1 & 5 & 4 & $3^{*}$ & 2 & $\mathbf{0}$ & 1 & 2 & 2 & 0 & $4 \cdot 3$ \\
\hline Good monsoon & Lows & 382 & 55 & 9 & 7 & 2 & 1 & 2 & 1 & $\mathbf{0}$ & 0 & $2 \cdot 1$ \\
\hline Bad monsoon & Lows & 311 & & 7 & 3 & $\mathbf{0}$ & $\mathbf{0}$ & 1 & 0 & & $\mathbf{0}$ & $1 \cdot 9$ \\
\hline
\end{tabular}

* One depression which originated on the last day of August and continued upto 3 September has been included in this statistics. 
Table 4. Number of monsoon depressions/lows, number of disturbed and undisturbed days over India (July-August) in composited years (based on 5 year statistics for each type).

\begin{tabular}{|c|c|c|c|c|c|c|c|}
\hline \multirow{2}{*}{$\begin{array}{l}\text { Composited } \\
\text { years type }\end{array}$} & \multicolumn{2}{|c|}{ No. of systzms } & \multirow{2}{*}{$\begin{array}{l}\text { Depres- } \\
\text { sion } \\
\text { days }\end{array}$} & \multirow{2}{*}{$\begin{array}{l}\text { Low } \\
\text { days }\end{array}$} & \multirow{2}{*}{$\begin{array}{l}\text { Two } \\
\text { system } \\
\text { days }\end{array}$} & \multirow{2}{*}{$\begin{array}{l}\text { No. of } \\
\text { disturbed } \\
\text { days }\end{array}$} & \multirow{2}{*}{$\begin{array}{l}\text { No. of } \\
\text { undisturbed } \\
\text { days }\end{array}$} \\
\hline & Depression & Lows & & & & & \\
\hline $\begin{array}{l}\text { Good monsoon } \\
\text { (average for } \\
5 \text { years) }\end{array}$ & $\begin{array}{c}21 \\
(4 \cdot 1)\end{array}$ & $\begin{array}{c}85 \\
(17 \cdot 0)\end{array}$ & $\begin{array}{c}82 \\
(16 \cdot 4)\end{array}$ & $\begin{array}{c}150 \\
(30 \cdot 0)\end{array}$ & $\begin{array}{c}25 \\
(5 \cdot 0)\end{array}$ & $\begin{array}{c}232 \\
(46 \cdot 4)\end{array}$ & $\begin{array}{c}78 \\
(15 \cdot 6)\end{array}$ \\
\hline $\begin{array}{l}\text { Bad monsoon } \\
\text { (average for } \\
5 \text { years) }\end{array}$ & $\begin{array}{c}20 \\
(4 \cdot 0)\end{array}$ & $\begin{array}{c}54 \\
(10 \cdot 8)\end{array}$ & $\begin{array}{c}83 \\
(16 \cdot 6)\end{array}$ & $\begin{array}{c}88 \\
(17 \cdot 6)\end{array}$ & $\begin{array}{c}10 \\
(2 \cdot 0)\end{array}$ & $\begin{array}{c}171 \\
(34 \cdot 2)\end{array}$ & $\begin{array}{c}139 \\
(27 \cdot 8)\end{array}$ \\
\hline $\begin{array}{l}\text { Ratio of good and } \\
\text { bad monsoon years } \\
\text { composites }\end{array}$ & $1 \cdot 1$ & $1 \cdot 6$ & $1 \cdot 0$ & $1 \cdot 7$ & $2 \cdot 5$ & $1 \cdot 4$ & 0.6 \\
\hline
\end{tabular}

The good monsoon years composite is characterised by higher number of 'lows' as well as low days. The number of undisturbed days in the case of good monsoon years composite is also considerably smaller.

If we remove the number of average 'break days' (as given in table 2) from the average number of undisturbed days (as given in table 4) we get the following figures for the average undisturbed days without the break monsoon conditions during July and August.

Composite type Undisturbed days without 'break' monsoon (July and August) conditions (July and August)

$$
\begin{array}{ll}
\text { Good monsoon years } & 12.4 \text { days } \\
\text { Bad monsoon years } & 14.0 \text { days }
\end{array}
$$

Undisturbed days without 'break' monsoon conditions are obviously characterised by the presence and activity of the regional monsoon trough in near normal position (without any embedded disturbance). As on the average the number of such undisturbed days (without 'break' monsoon conditions) is more or less the same in July-August of good (12.4 days) and bad (14 days) monsoon years, we may conclude that on the average the contribution of large scale monsoon trough to the rainfall of July-August in good and bad monsoon years remains more or less the same.

From the above preliminary and simple analyses we are led to the tentative conclusion that on the average during good monsoon years the monsoon trough is characterised by greater frequency of instability which manifests itself in the higher number of 'monsoon lows' and 'disturbed days' and consequently contributes to the higher than normal rainfall. The nature of this instability and the 
mechanism which operates it more frequently during the good monsoon years is not within the scope of this study. Further work is, however, required to exactly quantify the rainfall which is associated with different types of synoptic scale systems which form and move over the Indian region during the summer monsoon.

\subsection{Temperature anomaly}

Keshvamurty and Awade (1974) while studying the abnormalities associated with the drought of 1972 found that the thickness field between 1000 and $300 \mathrm{mb}$ to the north and northwest of India was dominated by below normal values implying colder than normal tropospheric temperature over these regions. We have computed $500 \mathrm{mb}$ temperature anomaly along $30^{\circ} \mathrm{N}$ averaged for the AfroAsian belt along $30^{\circ} \mathrm{E}$ to $120^{\circ} \mathrm{E}$ from the mean monthly charts published by the USSR. The computed temperature anomalies for the months of May, June, July, August and September and for the years 1972 to 1976 are shown in figure 5. It is seen that the drought years 1972 and 1974 were colder than the normal but so was also the year 1973 during which the performance of monsoon rainfall was satisfactory. The two good monsoon years 1975 and 1976 had either near normal temperatures or slightly above normal. Thus we find some evidence in these five years, although not in all cases that colder temperatures at $500 \mathrm{mb}$ over northern India and adjoining regions are associated with below normal monsoon rainfall over India.

\section{Concluding remarks}

Extended periods of droughts over India on the decadal scales are found to be intersparsed with extended wet periods. On the decadal scale or for epochs comprising of several years, failures of summer monsoon rainfall of India tends

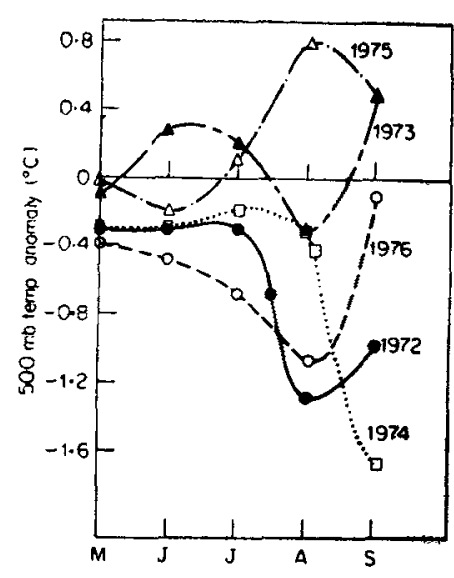

Figure 5. Year-to-year variations in the $500 \mathrm{mb}$ temperature anomaly averaged for the longitudinal belt $30-120^{\circ} \mathrm{E}$ along $30^{\circ} \mathrm{N}$.

P. (A)-7 
to agree with epochs of below normal tropospheric temperatures over the northern hemisphere as well as greater frequency of El-Nino events in the equatorial midPacific. This suggests that performance of monsoon rains on longer temporal scale are influenced by the planetary scale features such as the intensity of Hadley Cell and the Walker Circulation which depend upon the variations in meridional and zonal temperature gradients respectively. It must be recognised that these relationships are not valid on strictly year-to-year basis. Perhaps we should not expect them to be so as the extreme events of a climatic system may operate in the same years or with some lag. Available evidence discussed in this study does not clearly show whether the monsoon failure occurs after the El-Nino event or precedes it but the two events seem to be related in a complex manner.

Several parameters of the Indian summer monsoon circulation on the regional scale have been compared for the composites of five good and five bad monsoon years. The characteristics of monsoon depression studied are found to be by and large similar in the two types of composites. The parameters which are found to clearly distinguish between the two types of composites are (i) the position of monsoon trough in the lower troposphere, (ii) magnitude of cyclonic vorticity in the zone of monsoon trough at $850 \mathrm{mb}$, (iii) number of break monsoon days, (iv) number of lows and (v) number of 'low' days. The greater number of monsoon lows and 'low' days in good monsoon years composite may contribute to the southward position of monsoon trough, higher magnitude of cyclonic vorticity at $850 \mathrm{mb}$, less number of 'break' monsoon days and consequently higher amount of rainfall in comparison to bad monsoon years composite. Thus, one of the most important aspects which emerges from this study is that on the average during good monsoon years the monsoon trough zone is more frequently cyclogenetic (depressions and lows included). Further work is obviously needed to investigate the basic mechanism which leads to frequent instability of the monsoon trough zone in order to understand the dynamics of monsoon system.

\section{References}

Angell J K and Korshover K 1977 Mon. Weather Rev. 105375

Bjerkenos J 1969 Mon. Weather Rev. 97163

Blanford H $1882 \mathrm{Mem}$. Indian Met. Dept. 31

Chiu W C and Lo A 1979 Mon. Weather Rev. 10718

Dallas W L $1900 \mathrm{Mem}$. Indian Met. Dept. 121

Dhar O N, Rakhecha P N and Mandal B N 1978 Weather 33196

Harley W S 1978 Mon. Weather Rev. 106413

Hasternath S 1976 J. Atmos. Sci. 33202

Joseph P V 1976 Proc. Symp. Tropical Monsoons (Poona: Ind. Inst. of Trop. Meteor.) p. 378

Kanamitsu M and Krishnamurti T N 1978 Mon. Weather Rev. 106331

Keshvamurty R N and Awade S T 1974 Indian J. Met. Geophys. Hydrol. 25257

Koteswaram P 1960 Monsoons of the world India Met. Deptt. p. 105

Krishnamurty T N 1971 J. Atmos. Sci. 281342

Lamb P 1978 Tellus 30240

Matson M 1977 NOAA Tech. Mem. NESS 841966

Miles M K 1978 Nature (London) 276356

Mossman R C 1924 Mem. Indian Met. Dept. 23157 
Murakami T 1974 Atmospheric response to heat sources during July. UHMET-74-04, Deptt. of Met. Univ, of Hawaii.

Normand C W B 1953 Q. J.R. Meteorol. Soc. 70463

Parthasarathy S and Mooley D A 1978 Mon. Weather Rev. 106771

Paul D K and Sikka D R 1975 Monsoon sea level pressure field, Sci. Report Ind. Institute of Tropical Meteorology, Poona

Quinn W H 1974 J. Appl. Meteor. 13825

Ramage C S 1969 Year Book of ASS of Pacific Coast Geographers 3041

Ramage C S 1971 Monsoon Meteorology, Int. Geophys., Ser. (New York, London : Academic Press) 15, p. 296

Ramage C S 1977 Mon. Weather Rev. 105540

Rao Y P 1976 Southwest monsoon, Meteor. Monogr. No. 1, 1976, India Met. Dept. pp. 367 Reiter E R 1978 Mon. Weather Rev. 106324

Rowntree P R 1978 Paptr presented at Conference on Meteorology over the Tropical Oceans, London, Aug. 1978

Sikka D R 1977 Pageoph 115 1501, 1529

Sikka D R and Gadgil S 1978 Indian Met. J. Hydrol. Geophys. 29219

Walker G T 1924 Mem. Indian Met. Dept. 24275

Walker G T 1928 Q. J. R. Meteor. Soc. 5479 